\title{
GJB2 Gene Related Nonsyndromic Hearing Loss in Mazandaran Province, North of Iran
}

\section{Elaheh Hosseini' ${ }^{1}$, Seyed Saeid Mousavi ${ }^{1}$, Atefeh Khoshaein ${ }^{2}$, Fatemeh Daneshpour ${ }^{3}$, Moosa Rajabi Vandchali ${ }^{4}$, S. Mohammad Bagher Hashemi-Soteh ${ }^{*}$}

\author{
${ }^{1}$ Novin Genetic Diagnostic Laboratory, Sari, Iran \\ ${ }^{2}$ Mehregan Genetic Counseling Center, Sari, Iran \\ ${ }^{3}$ Novin Genetic Counseling Center, Sari, Iran \\ ${ }^{4}$ Genetic Counseling Center, State Welfare Organization of Mazandaran Province, Sari, Iran \\ ${ }^{5}$ Immunogenetic Research Center, Molecular and Cell Biology Research Center, Faculty of Medicine, \\ Mazandaran University of Medical Sciences, Sari, Iran
}

Email: ^hashemisoteh@mazums.ac.ir

How to cite this paper: Hosseini, E., Mousavi, S.S., Khoshaein, A., Daneshpour, F., Vandchali, M.R. and Hashemi-Soteh, S.M.B. (2020) GJB2 Gene Related Nonsyndromic Hearing Loss in Mazandaran Province, North of Iran. Open Journal of Genetics, 10, 51-63.

https://doi.org/10.4236/ojgen.2020.103005

Received: August 13, 2020

Accepted: September 27, 2020

Published: September 30, 2020

Copyright $\odot 2020$ by author(s) and Scientific Research Publishing Inc. This work is licensed under the Creative Commons Attribution International License (CC BY 4.0).

http://creativecommons.org/licenses/by/4.0/

\begin{abstract}
Introduction: Congenital hearing loss is the most common sensory deficit in the world and mutations in $G J B 2$ gene are the most common cause of deafness in many populations. Frequency of $G J B 2$ mutations is estimated about $16 \%$ in Iran and varies among different provinces with a decreasing trend from north to south. The aim of this study was to investigate the frequency of GJB2 mutations in Mazandaran province, north of Iran, among non-syndromic hearing loss patients. Methods: 262 patients from 204 families participated in this study. After genomic DNA extraction, GJB2 gene analysis was carried out using DNA sequencing of both coding and non-coding regions by ABI 3130XL genetic analyzer. Results: $30.15 \%$ of all subjects showed mutations in $G J B 2$ gene. Four mutations, including c.35delG (Gly12Valfs ${ }^{\star}$ ), IVSI-1 + $1 \mathrm{G}>$ A, c.95G > A (Arg32His) and c.224 G > A (Arg75Gln) comprises $69.89 \%$ of all mutations in this study c.35delG and IVSI-1 were the most common mutations among patients respectively. Codon 75 mutation (c.224G > A. p: Arg75Gln) with autosomal dominant inheritance was seen in 7 cases from 3 families. 22 patients showed only one mutation in GJB2 gene and in 126 (48.09\%) individuals, parents had a consanguineous marriage. Discussion: Frequency of $G J B 2$ gene related hearing loss among patients was higher than average (16\%) in this province. This study also showed a dominant inheritance pattern of $G J B 2$ gene in this area. Consanguineous marriage also showed highly frequent among parents. More investigation needs to clarify cause of hearing loss in those 22 patients with one mutation in GJB2 gene, either two gene inheritance or another gene may be responsible for hearing loss.
\end{abstract}




\section{Keywords}

Hearing Loss, GJB2, Mazandaran, Hereditary Deafness, Nonsyndromic

\section{Introduction}

Deafness is one of the most common diseases in the world which is caused by hereditary or environmental factors or a combination of both [1] [2]. Congenital deafness has a prevalence of 1.3 per 1000 population and in $70 \%$ of cases is not associated with other clinical symptoms [3] [4] [5] [6]. Between 75\% - 80\% cases of non-syndromic deafness are inherited in an autosomal recessive pattern. Generally the frequency of hearing loss is reported 1 in 1000 live births in US and developed countries. The prevalence of deafness in Iran is higher due to the high rate of consanguineous marriages, approximately 3 per 1000 [7] [8]. This disorder is extremely heterogeneous and more than 150 genes are identified causing deafness to date. So far, 121 genes responsible for non-syndromic deafness have been identified, of wich76 genes have autosomal recessive inheritance, others have autosomal dominant (54 genes) and X-linked (5 genes) inheritance (http://hereditaryhearingloss.org).

GJB2 gene, located at 13q12 and encodes Gap Junction beta2 protein, also known as connexin 26 protein and is necessary for cells to communicate with each other. This protein is localized in the cochlea and plays a role in $\mathrm{k}+$ recycling pathway during auditory transduction [9] [10]. Different types of mutation in $G J B 2$ gene such as Missense, Nonsense and frameshift are the most common cause of non-syndromic deafness with autosomal recessive inheritance pattern. Although some mutations in this gene have been reported to be associated with autosomal dominant inheritance pattern [11]. So far, more than 300 pathogenic mutations have been reported for $G J B 2$ gene that is associated with autosomal recessive non-syndromic deafness (http://databases.lovd.nl/shared/genes/GJB2). The most frequent mutations in this gene is c.35delG that occurs due to a $\mathrm{G}$ deletion in a sequence of 6 guanines from position 30 - 35 coding are and cause a frameshift and premature stop codon [11] [12] [13] [14].

The type and prevalence of mutations vary in different populations. The frequency of $G J B 2$ mutations is reported from different provinces in Iran. It is generally as high as $22 \%$ to $38 \%$ in West Azarbaijan and East Azarbaijan province, Gilan and Golestan in the north and northwest provinces, to the average level of $16 \%$ in central provinces like Qom, Kerman, Isfahan, Yazd, Lorestan and as low as $4 \%$ to $0 \%$ in South Provinces like Sistan and Baluchestan [14] [15]. In general, it is estimated about $16 \%$ prevalence for GJB2 related hearing loss in Iran [14] [15]. Consanguineous marriage increases the frequency of homozygousity. It is estimated that $38 \%$ of the marriage is consanguineous and approximately $70 \%$ of cases are first cousins [16]. Also about 30,000 to 40,000 children are born every year with congenital disorders such as deafness [17] [18]. 
Deaf persons often require different kinds of medical care, specialized education and social services, reduced work productivity which leads extra cost to the society. Although GJB2 mutations are highly frequent in Northern provinces in Iran (Golestan, Mazandaran and Gilan), there are very few previous reports about GJB2 gene mutation frequency from Mazandaran province. The aim of this study was to investigate the frequency of $G J B 2$ mutations in Mazandaran province, which could be useful for genetic counseling and prenatal diagnosis.

\section{Materials and Methods}

\subsection{Subject}

This prospective study was recruited 262 patients from 204 families with hearing loss from Mazandaran province, north of Iran who referred to Novin genetic diagnostic laboratory and counseling center, during the 11-year period, 2009-2020). After genetic counseling, family who was suspected to the hereditary form of hearing loss was included in this study. Any hearing loss with environmental cause was excluded from this study. All ethical issues, including confidentiality and informed consent were included in this study. All subjects were informed and were approved by the ethics committee of Mazandaran University of Medical Sciences.

\subsection{DNA Extraction and PCR Amplification}

A total of 5 to $10 \mathrm{ml}$ of peripheral blood was collected in a EDTA container tube from each person, then genomic DNA was extracted according to established protocols [19] [20]. The quality and quantity of DNA samples were measured by Nanodrop spectrophotometer (Thermo Sci., Newington, NH). Two appropriate pairs of primers (Table 1) were applied (Macrogene, South chorea) to amplify exon 1 and exon 2 of $G J B 2$ gene using polymerase chain reaction (PCR) followed by DNA sequencing method. A $850 \mathrm{bp}$ and a $950 \mathrm{bp}$ fragment was achieved by PCR amplification in a total volume of $25 \mu \mathrm{l}$ respectively. Briefly, $2 \mu \mathrm{M}$ of each primer $(0.7$ $\mu \mathrm{l}), 0.1 \mathrm{mM}$ each dNTP $(0.5 \mu \mathrm{l}), 1 \times$ PCR buffer $(2.5 \mu \mathrm{l}), 1.5 \mathrm{mM} \mathrm{MgCl}_{2}(0.7 \mu \mathrm{l}), 0.5$ unit of Taq polymerase $(0.2 \mu \mathrm{l})$ and $19.3 \mu$ distillated water (Cinnagen, Iran) were used in each PCR tube. The following amplification conditions: initially denatured at $95^{\circ} \mathrm{C}$ for 5 minute, followed by 35 cycles of denaturation at $95^{\circ} \mathrm{C}$ for 1 minute, annealing at $60^{\circ} \mathrm{C}$ for 1 minute and extension at $72^{\circ} \mathrm{C}$ for 1 minute and a final extension at $72^{\circ} \mathrm{C}$ for $5 \mathrm{~min}$. Quality of PCR product was checked by electrophoresis, $5-\mu \mathrm{l}$ of each PCR product on was run on $1 \%$ agarose gel.

Table 1. Specific primers to amplify exon 1 and exon 2 of the GJB2 gene.

\begin{tabular}{lc}
\hline Exon 1: Forward & 5'-GTGCGGTTAAAAGGCGCCAC-3' \\
Exon 1: Reverse & 5'-GGTGCCATCGCGTCCACTT-3' \\
Exon 2: Forward & 5'-TGCTTGCTTACCCAGACTCA-3' \\
Exon 2: Reverse & 5'-TTGTGGCATCTGGAGTTTCA-3' \\
\hline
\end{tabular}




\subsection{DNA Sequencing and Genotype Analysis}

Samples were subjected to further investigations using Sanger sequencing 3130XL Genetic Analyzers (ABI applied Biosystem, USA) for all individuals as a part of the diagnostic genetic laboratory services. In brief, specific primers were used to amplify entire exonic as well as 5 ' and $3^{\prime}$ flanking intronic regions of the exon1 and exon2 of $G J B 2$ gene, followed by DNA sequencing to find any variations or short deletion/insertions as described previously. Sequence analysis was performed using reference sequences from GenBank database. Gene Runner software (http://www.generunner.com) was used to align patient's gene sequence, and Ref. sequence along with manual check of chromatogram from patient's DNA sequence using FinchTV chromatogram viewer software (Geospiza) also was applied [19] [20].

\subsection{Statistical Analysis}

Statistical analysis was performed using descriptive statistics. Allelic and genotype frequencies of the study variants were reported using basic descriptive statistics.

\section{Results}

262 patients from 204 families with hearing loss, including 154 severe were screened for $G J B 2$ gene. 79 individuals (30.15\%) showed mutations in GJB2 gene, which 72 individuals (27.48\%) had two mutations with autosomal recessive inheritance and 7 individuals (2.67\%) showed one mutation with autosomal dominant inheritance in GJB2 gene (Figure 1). Also 161 (61.45\%) individuals showed no mutations in $G J B 2$ gene. From 262 patients, 22 (8.39\%) individuals showed only one recessive mutation in GJB2 gene and were carrier (Table 2 and Figure 1).

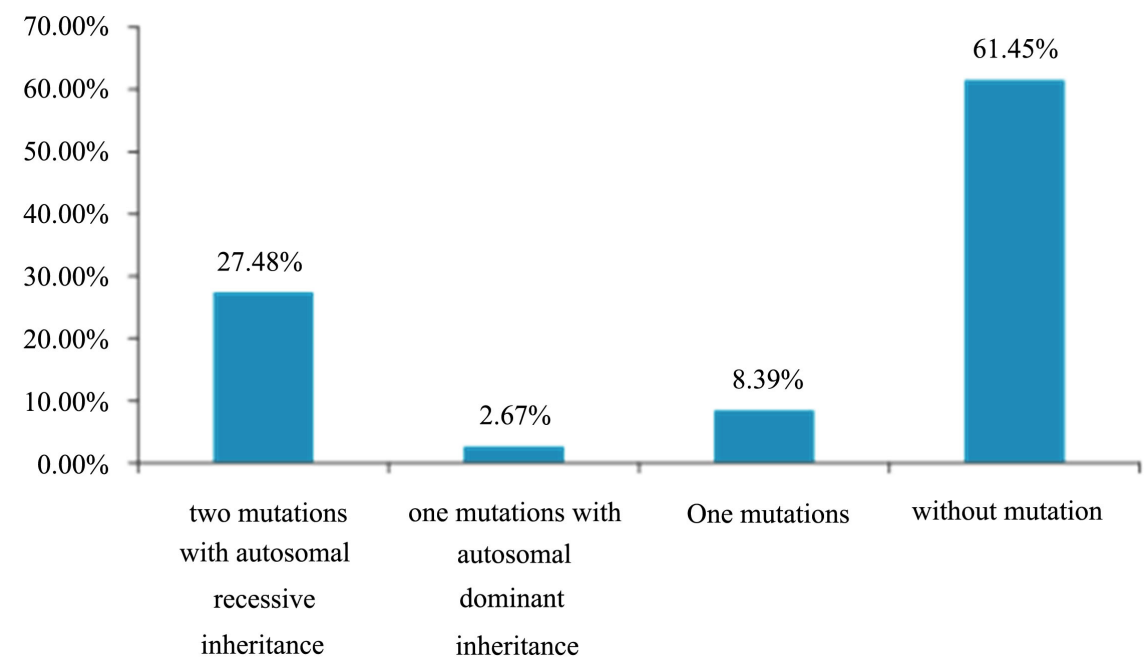

Figure 1. Frequency of autosomal recessive, autosomal dominance and individuals with one mutation in GJB2. 61.45\% showed no mutation in GJB2 gene $(\mathrm{n}=262)$. 
Table 2. Carrier frequency for $G J B 2$ allele variant in 183 deaf individuals in whom GJB2 related hearing loss could not be identified $(n=22)$.

\begin{tabular}{cccc}
\hline Genotype & Codon change & Total case & Frequency (\%) \\
\hline IVSI + 1G > A/_ & Gly12Val fs/_ & 8 & 36 \\
c.35delG/_ & Arg127His/_ & 3 & 31.8 \\
c.380G > A/_ & Arg32His/_ & 2 & 13.6 \\
c.95G > A/_ & Gly160Ser/_ & 1 & 9 \\
c.478G $>$ A/_ & Asp46Glu/_ & 1 & 4.5 \\
c.138T $>$ G/_ & & 22 & 4.5 \\
Total & &
\end{tabular}

$35 \mathrm{delG}$ and IVSI-1 $+1 \mathrm{G}>\mathrm{A}$ were the most common mutations among patients in this study, respectively (Table 1). Also 4 mutations, including c.35delG (Gly12Valfs), IVSI-1 + 1G > A, c.95G > A (Arg32His) and c.224 G > A (Arg75Gln) comprises $91.27 \%$ of all mutations among 173 mutant alleles in this study (Table 3). Codon 75 mutation (Arg75Gln) with autosomal dominant inheritance was seen in 7 cases from 3 families. Two polymorphisms (c.457G > A and c.79G > A) also were seen in this study with total frequency of $2.28 \%$.

Genotype composition and genotype frequency of the patients are shown in Table 4. As it is expected, homozygous patients for three most frequent recessive mutations are more common among patients (Table 3). In 126 (48.09\%) individuals, parents had consanguineous marriage. Three family pedigrees, one with autosomal dominant and two with autosomal recessive inheritance are shown in Figure 2.

\section{Discussion}

The GJB2 gene related hearing loss in Iran varies between 35\% to zero, shows a decreasing trend from north to south of the country with average about $16 \%$ according to the previous studies [21] [22] [23] [24]. GJB2 gene-related hearing loss is generally higher in the North and is reported as high as $38 \%$ in some area in Gilan and Golestan provinces [15]. A previous study performed by Najmabadi et al. in 664 autosomal recessive non-syndromic hearing loss families from different geographic areas including 47 probands from North of Iran reported $38.3 \%$ frequency of $G J B 2$ gene related hearing loss [25]. Also in another study by Bazazzadegan et al., which was conducted on 2322 families from 31 provinces of Iran during twelve years, the highest prevalence of GJB2 gene mutations was belongs to the north of Iran, with 33\% in Mazani and Gilaki ethnic groups [26]. In this study that 262 deaf individuals from Mazandaran province were recruited, the results showed that the frequency of $G J B 2$ mutations related non-syndromic hearing loss was $30.15 \%$ respectively. 4 mutations, including c.35delG, IVSI-1G > A, c.95G > A and c.224G > A accounted for about $70 \%$ of all detected mutations. 


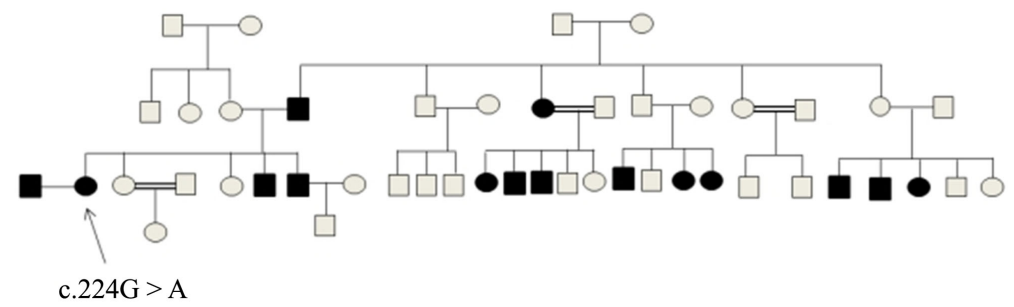

(a)

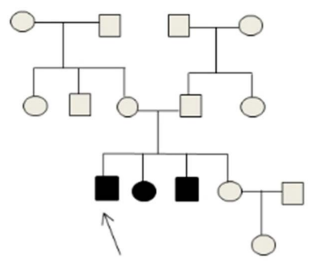

c.35delG/c.35delG

(b)

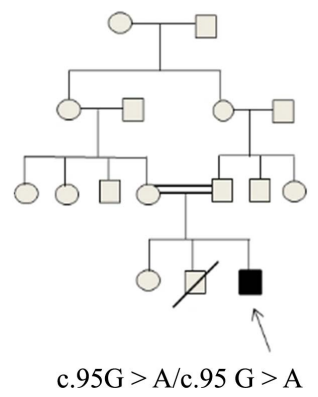

(c)

Figure 2. A: example of autosomal dominant pedigree in one family with c.224A $>$ G (Arg75Gln) mutation. A relatively big family with 15 affected members. B \& C: Two family pedigree that shows c.35delG and c.95G > A (Arg32His) mutation with autosomal recessive inheritance.

Table 3. Number and prevalence of different mutations found in $G J B 2$ gene in affected individuals with hearing loss $(\mathrm{n}=262)$.

\begin{tabular}{|c|c|c|c|}
\hline Mutation & Codon change & Number of alleles & Frequency (\%) \\
\hline c.35delG & Gly12Val fs & 108 & 62.42 \\
\hline $\mathrm{IVS} 1+1 \mathrm{G}>\mathrm{A}$ & & 25 & 14.45 \\
\hline c. $95 \mathrm{G}>\mathrm{A}$ & Arg32His & 18 & 10.4 \\
\hline c. $224 \mathrm{G}>\mathrm{A}$ & Arg75Gln & 7 & 4 \\
\hline c. $551 \mathrm{G}>\mathrm{C}$ & Arg184Pro & 5 & 2.8 \\
\hline c. $380 \mathrm{G}>\mathrm{A}$ & Arg127His & 3 & 1.73 \\
\hline c. $478 \mathrm{G}>\mathrm{A}$ & Gly160Ser & 2 & 1.15 \\
\hline c. $138 \mathrm{~T}>\mathrm{G}$ & Asp46Glu & 1 & 0.57 \\
\hline c. $274 \mathrm{G}>\mathrm{T}$ & Ala92Ser & 1 & 0.57 \\
\hline c. $229 \mathrm{~T}>\mathrm{C}$ & Trp77Arg & 1 & 0.57 \\
\hline c. $428 \mathrm{G}>\mathrm{A}$ & Arg143Gln & 1 & 0.57 \\
\hline c. $71 \mathrm{G}>\mathrm{A}$ & Trp24Ter & 1 & 0.57 \\
\hline c. $408 \mathrm{C}>\mathrm{A}$ & Tyr136Ser & 1 & 0.57 \\
\hline \multicolumn{2}{|c|}{ Total } & 173 & \\
\hline
\end{tabular}


Table 4. List of GJB2 genotype with biallelic recessive pathogenic mutation in 72 deaf individuals.

\begin{tabular}{rccc}
\hline Genotype & Codon change & Total case & Frequency (\%) \\
\hline c.35delG/c.35delG & Gly12Val fs/Gly12Val fs & 43 & 16.41 \\
c.95G > A/c.95G > A & Arg32His/Arg32His & 7 & 2.67 \\
IVSI + 1G > A/IVSI + 1G > A & & 2 & 0.76 \\
c.551G > C/c.551G > C & Arg184Pro/Arg184Pro & 1 & 0.38 \\
c.35delG/ IVSI + 1G > A & Gly12Val fs/IVSI + 1G > A & 9 & 3.43 \\
c.35delG/c.551G > C & Gly12Val fs/Arg184Pro & 2 & 0.76 \\
c.35delG/c.229T > C & Gly12Val fs/Trp77Arg & 1 & 0.38 \\
c.35delG/c.95G > A & Gly12Val fs/Arg32His & 1 & 0.38 \\
c.478G > A/IVSI + 1G > A & Gly160Ser/IVSI + 1G > A & 1 & 0.38 \\
IVSI + 1G > A/c.408C > A & IVSI + 1G > A/Tyr136Ser & 1 & 0.38 \\
c.95G > A/IVSI + 1G > A & Arg32His/IVSI + 1G > A & 1 & 0.38 \\
c.551G > C/IVSI + 1G > A & Arg184Pro/IVSI + 1G > A & 1 & 0.38 \\
c.35delG/c.428G > A & Gly12Val fs/Arg143Gln & 1 & 0.38 \\
c.35delG/c.71G > A & Gly12Val fs/Trp24Ter & 1 & 0.38 \\
Total & & 72 & \\
\hline
\end{tabular}

c.35delG was the most common GJB2 mutation accounted for 108 out of 226 (47.78\%) mutated alleles in this study. c.35delG first was reported by Zlante et al. 1997 [27]. In Caucasians, this mutation is responsible for $20 \%$ of all hereditary hearing loss [28] [29] [30]. Frequency of c.35delG carrier is reported $1.26 \%$ in Northern Europe and $1.96 \%$ in Southern Europe [31] [32]. Also its' frequency is reported 1.52\%, 0.64\%, $1 \%$ and $0.64 \%$ among American, Asian, Oceanic, and African populations respectively [4] [32]. In Azarbayjan population, Iran neighbor, frequency of c.35delG mutation has been estimated 18\% [33] and in Turkish population, it is reported 5\% - 53\% respectively [34]. In Iran, c.35delG also is the most frequent mutation among deaf individuals [22] [35] [36]. The c.35delG frequency is more in North and Northwest comparing to south of the country [23] [37]. In one study on 298 familial and 592 sporadic subjects from ten provinces, c.35delG was the most prevalent mutation accounted for 193 out of $259(74.5 \%)$ of the GJB2 mutated alleles [35]. Also, c.35delG frequency was reported 27\%, 9.1\% and 18\% for Gilan, Golestan and East Azarbayjan provinces in the north and $0 \%$ in Sistan and Baluchestan province in the south respectively [35]. In this study, from 524 alleles tested, 108 (20.64\%) had c.35delG mutation, which is similar to the finding of previous studies.

IVSI $+1 \mathrm{G}>\mathrm{A}$ is a splice site mutation in non-coding exon 1 of the $G J B 2$ gene that was reported by Denoyelle et al. [38]. It has been found in several populations and frequent among Czech, Hungarian, Yakut and Turkish [39] [40]. This mutation is the third most common GJB2 mutation in Czech [39] and also it is reported $4.33 \%$ with total allele frequency in Turkish population [41] [42]. In 
Iran, the IVS1 $+1 \mathrm{G}>\mathrm{A}$ is one of five most prevalent $G J B 2$ mutations with frequency about 4.5\% [23], with as high as 9.1\%in Kurdish ethnic group [14] [43]. Results from this study also showed IVS1 $+1 \mathrm{G}>\mathrm{A}$ as a second most common mutation in Mazandaran with the frequency of $14.45 \%$ (25 of 226) of the GJB2 mutated chromosomes.

c.95G > A (Arg32His) is a third most frequent mutation accounted for $10.4 \%$ (18 out of 173) mutated chromosomes in this study. Previous studies reported in one out of 70 consanguineous families from Isfahan, estimated $2.5 \%$ frequency in central area of Iran [44], 5 out of 1328 total allele tested (0.37\%) in other study [25] and also 2 out of 131 (1.52\%) in an unrelated nonsyndromic hearing loss samples from central part of Iran [1]. Results achieved from this study revealed slightly higher frequency of $3.43 \%$ ( 18 out of 524 alleles) from total chromosome studied.

c.224G > A (Arg75Gln) cause autosomal dominant hearing loss [26]. In this study, 7 individuals from 3 families ( 7 out of 173 affected alleles) (4\%) were seen with this mutation, with non-syndromic hearing loss (Table 1 and Figure 1). To date, 54 dominant mutations in GJB2 gene have been identified worldwide (http://hereditaryhearingloss.org), of which about two-third can cause syndromic hearing loss and remaining causes autosomal dominant non-syndromic hearing loss [26] [45].

For those 22 patients who showed only one mutation in $G J B 2$ gene, a digenic inheritance could be involved or another gene rather than $G J B 2$ may be responsible for hearing loss. Because hearing loss is heterogeneous, so it is a good candidate for digenic inheritance [46]. Several examples of digenic inheritance have been reported for hearing loss, such as PCDH15 and CDH23, SLC26A4 and FOX1, SLC26A4 and KCNJ10, MYO7A and PCDH15, PCDH and USH1G [47]. For $G J B 2$ gene, different digenic inheritance including $G J B 2$ and $G J B 6, G J B 2$ and GJB3, GJB2 and MIFT has been reported before [48] [49] [50]. More investigation is needed to find other mechanisms that are involved.

c.457G > A, (Val153Ile) substitution was seen 12 out of 262 (4.58\%) deaf individuals. This change has been reported as a pathogenic allele with recessive inheritance [51] [52] as well as a polymorphism [53] [54]. In one study, Mes et al. demonstrate that the $c .457 \mathrm{G}>\mathrm{A}$ change could be pathogenic as they showed that mutated protein was unable to form functional channels in Xenopus oocyte expression system [55]. In another review study, Mahdieh et al. revealed c.457G > A with a frequency of 93 out of 148 (62.84\%) among polymorphic alleles and $2.4 \%$ in total reported alleles and concluded it as a polymorphism [22]. Similarly, Bazzazzadegan et al. found 64\% (89 out of 4644 alleles) in 2322 nonsyndromic hearing loss probands from different ethnics in Iran and conclude this change is a polymorphism [23]. The pathogenic effect of this amino acid substitution is controversial and remains to be confirmed.

Finally, our finding showed that 79 individuals (30.15\%) showed mutations in GJB2 gene in this study, also in 161 individuals (61.45\%), GJB2 gene was not involved in their hearing problem. This study also showed dominant inheritance 
of $G J B 2$ gene in this area. Along with mutation detection, also we found that about $48 \%$ of patients resulted from consanguineous marriage. There was also some limitation in this study. The audiometry test result from all patients was not available, so the exact phenotype-genotype correlation study was not possible in this investigation. As deafness is a heterogeneous disease, in cases that GJB2 gene is not responsible for the disease, another gene may involve, so analysis of all other known genes for hearing loss needs to be analyzed using next generation sequencing system.

\section{Acknowledgements}

We would like to thank those patients who participate in this study and also the Novin Genetic Laboratory members who helped us during this study.

\section{Conflicts of Interest}

The authors declare no conflicts of interest regarding the publication of this paper.

\section{References}

[1] Naddafnia, H., Noormohammadi, Z., Irani, S. and Salahshoorifar, I. (2019) Frequency of GJB2 Mutations, GJB6-D13S1830 and GJB6-D13S1854 Deletions among Patients with Non-Syndromic Hearing Loss from the Central Region of Iran. $\mathrm{Mo}$ lecular Genetics \& Genomic Medicine, 7, e00780. https://doi.org/10.1002/mgg3.780

[2] Nance, W.E. (2003) The Genetics of Deafness. Mental Retardation and Developmental Disabilities Research Reviews, 9, 109-119.

https://doi.org/10.1002/mrdd.10067

[3] Adadey, S.M., Manyisa, N., Mnika, K., De Kock, C., Nembaware, V., et al. (2019) GJB2 and GJB6 Mutations in Non-Syndromic Childhood Hearing Impairment in Ghana. Frontiers in Genetics, 10, 841. https://doi.org/10.3389/fgene.2019.00841

[4] Esmaeili, M., Bonyadi, M. and Nejadkazem, M. (2007) Common Mutation Analysis of GJB2 and GJB6 Genes in Affected Families with Autosomal Recessive Non-Syndromic Hearing Loss from Iran: Simultaneous Detection of Two Common Mutations (35delG/del (GJB6-D13S1830)) in the DFNB1-Related Deafness. International Journal of Pediatric Otorhinolaryngology, 71, 869-873.

https://doi.org/10.1016/j.ijporl.2007.02.007

[5] Morton, N. (1991) Genetic Epidemiology of Hearing Impairment. Annals of the New York Academy of Sciences, 630, 16-31. https://doi.org/10.1111/j.1749-6632.1991.tb19572.x

[6] Bademci, G., Cengiz, F., Foster II, J., Duman, D., Sennaroglu, L., et al. (2016) Variations in Multiple Syndromic Deafness Genes Mimic Non-Syndromic Hearing Loss. Scientific Reports, 6, Article No. 31622. https://doi.org/10.1038/srep31622

[7] Beheshtian, M., Babanejad, M., Azaiez, H., Bazazzadegan, N., Kolbe, D., et al. (2016) Heterogeneity of Hereditary Hearing Loss in Iran: A Comprehensive Review. Archives of Iranian Medicine, 19, 720.

[8] Khalil, A., Karroum, S.B., Barake, R., Dunya, G., Abou-Rizk, S., et al. (2020) Post-Lingual Non-Syndromic Hearing Loss Phenotype: A Polygenic Case with 2 Biallelic Mutations in MYO15A and MITF. BMC Medical Genetics, 21, Article No. 1. 
https://doi.org/10.1186/s12881-019-0942-4

[9] Marziano, N.K., Casalotti, S.O., Portelli, A.E., Becker, D.L. and Forge, A. (2003) Mutations in the Gene for Connexin 26 (GJB2) That Cause Hearing Loss Have a Dominant Negative Effect on Connexin 30. Human Molecular Genetics, 12, 805-812. https://doi.org/10.1093/hmg/ddg076

[10] Snoeckx, R.L., Huygen, P.L., Feldmann, D., Marlin, S., Denoyelle, F., et al. (2005) GJB2 Mutations and Degree of Hearing Loss: A Multicenter Study. The American Journal of Human Genetics, 77, 945-957. https://doi.org/10.1086/497996

[11] Zheng, J., Ying, Z., Cai, Z., Sun, D., He, Z., Cao, Y., et al. (2015) GJB2 Mutation Spectrum and Genotype-Phenotype Correlation in 1067 Han Chinese Subjects with Non-Syndromic Hearing Loss. PloS One, 10, e0128691.

https://doi.org/10.1371/journal.pone.0128691

[12] Cifuentes Ovalle, L., Arancibia, M., Torrente Avendaño, M., Acuña, M., Farfán Reyes, C., et al. (2013) Prevalence of the 35delG Mutation in the GJB2 Gene in Two Samples of Non-Syndromic Deaf Subjects from Chile. Biological Research, 46, No. 3. https://doi.org/10.4067/S0716-97602013000300003

[13] Kaheel, H., Breß, A., Hassan, M.A., Shah, A.A., Amin, M., et al. (2017) Frequency of c. 35delG Mutation in GJB2 Gene (Connexin 26) in Syrian Patients with Nonsyndromic Hearing Impairment. Genetics Research International, 2017, Article ID: 5836525. https://doi.org/10.1155/2017/5836525

[14] Azadegan-Dehkordi, F., Bahrami, T., Shirzad, M., Karbasi, G., Yazdanpanahi, N., et al. (2019) Mutations in GJB2 as Major Causes of Autosomal Recessive Non-Syndromic Hearing Loss: First Report of c. 299-300delAT Mutation in Kurdish Population of Iran. Journal of Audiology \& Otology, 23, 20-26.

https://doi.org/10.7874/jao.2018.00185

[15] Koohiyan, M., Koohian, F. and Azadegan-Dehkordi, F. (2020) GJB2-Related Hearing Loss in Central Iran: Review of the Spectrum and Frequency of Gene Mutations. Annals of Human Genetics, 84, 107-113. https://doi.org/10.1111/ahg.12354

[16] Nouri, N., Nouri, N., Tirgar, S., Soleimani, E., Yazdani, V., et al. (2017) Consanguineous Marriages in the Genetic Counseling Centers of Isfahan and the Ethical Issues of Clinical Consultations. The Journal of Medical Ethics and History of Medicine, 10, 12.

[17] Hashemi-Soteh, M.B., Nejad, A.V., Ataei, G., Tafazoli, A., Ghasemi, D., et al. (2019) Knowledge and Attitude toward Genetic Diseases and Genetic Tests among Pre-Marriage Individuals: A Cross-Sectional Study in Northern Iran. International Journal of Reproductive BioMedicine, 17, 543.

[18] Rafiee, L. and Saadat, M. (2011) Prevalence of Consanguineous Marriages among Iranian Georgians. Journal of Biosocial Science, 43, 47-50.

https://doi.org/10.1017/S0021932010000295

[19] Hashemi-Soteh, S.M.B., Sarzare, F., Merat, F., Salehifar, E. and Shiran, M.-R. (2011) Frequencies of Three CYP2D6 Nonfunctional Alleles $\left(C Y P 2 D \sigma^{\star} 3{ }^{\star} 4\right.$, and $\left.{ }^{\star} 6\right)$ within an Iranian Population (Mazandaran). Genetic Testing and Molecular Biomarkers, 15, 821-825. https://doi.org/10.1089/gtmb.2011.0033

[20] Hashemi-Soteh, S.M.B., Shahabi-Majd, N., Gholizadeh, A.-R. and Shiran, M.-R. (2012) Allele and Genotype Frequencies of CYP2C9 within an Iranian Population (Mazandaran). Genetic Testing and Molecular Biomarkers, 16, 817-821. https://doi.org/10.1089/gtmb.2011.0301

[21] Najmabadi, H., Cucci, R.A., Sahebjam, S., Kouchakian, N., Farhadi, M., et al. (2002) GJB2 Mutations in Iranians with Autosomal Recessive Non-Syndromic Sensori- 
neural Hearing Loss. Human Mutation, 19, 572-572. https://doi.org/10.1002/humu.9033

[22] Mahdieh, N., Rabbani, B., Wiley, S., Akbari, M.T. and Zeinali, S. (2010) Genetic Causes of Nonsyndromic Hearing Loss in Iran in Comparison with Other Populations. Journal of Human Genetics, 55, 639-648. https://doi.org/10.1038/jhg.2010.96

[23] Bazazzadegan, N., Nikzat, N., Fattahi, Z., Nishimura, C., Meyer, N., et al. (2012) The Spectrum of GJB2 Mutations in the Iranian Population with Non-Syndromic Hearing Loss-A Twelve Year Study. International Journal of Pediatric Otorhinolaryngology, 76, 1164-1174. https://doi.org/10.1016/j.ijporl.2012.04.026

[24] Zeinali, S., Davoudi-Dehaghani, E., Azadmehr, S., DabbaghBagheri, S., Bagherian, H., et al. (2015) GJB2 c. $-23+1 \mathrm{G}>$ A Mutation Is Second Most Common Mutation among Iranian Individuals with Autosomal Recessive Hearing Loss. European Archives of Oto-Rhino-Laryngology, 272, 2255-2259. https://doi.org/10.1007/s00405-014-3171-7

[25] Najmabadi, H., Nishimura, C., Kahrizi, K., Riazalhosseini, Y., Malekpour, M., et al. (2005) GJB2 Mutations: Passage through Iran. American Journal of Medical Genetics Part A, 133, 132-137. https://doi.org/10.1002/ajmg.a.30576

[26] Bazazzadegan, N., Sheffield, A.M., Sobhani, M., Kahrizi, K., Meyer, N.C., et al. (2011) Two Iranian Families with a Novel Mutation in GJB2 Causing Autosomal Dominant Nonsyndromic Hearing Loss. American Journal of Medical Genetics Part A, 155, 1202-1211. https://doi.org/10.1002/ajmg.a.33209

[27] Zelante, L., Gasparini, P., Estivill, X., Melchionda, S., D’Agruma, L., et al. (1997) Connexin26 Mutations Associated with the Most Common form of Non-Syndromic Neurosensory Autosomal Recessive Deafness (DFNB1) in Mediterraneans. Human Molecular Genetics, 6, 1605-1609. https://doi.org/10.1093/hmg/6.9.1605

[28] Kelley, P., Harris, D., Comer, B., Askew, J., Fowler, T., et al. (1998) Novel Mutations in the Connexin 26 Gene (GJB2) That Cause Autosomal Recessive (DFNB1) Hearing Loss. The American Journal of Human Genetics, 62, 792-799. https://doi.org/10.1086/301807

[29] Toumpas, C.J., Clark, J., Harris, A., Beswick, R. and Nourse, C.B. (2015) Congenital Cytomegalovirus Infection Is a Significant Cause of Moderate to Profound Sensorineural Hearing Loss in Queensland Children. Journal of Paediatrics and Child Health, 51, 541-544. https://doi.org/10.1111/jpc.12776

[30] Petersen, M. and Willems, P. (2006) Non-Syndromic, Autosomal-Recessive Deafness. Clinical Genetics, 69, 371-392. https://doi.org/10.1111/j.1399-0004.2006.00613.x

[31] Prasad, S., Cucci, R., Green, G. and Smith, R. (2000) Genetic Testing for Hereditary Hearing Loss: Connexin 26 (GJB2) Allele Variants and Two Novel Deafness-Causing Mutations (R32C and 645-648delTAGA). Human Mutation, 16, 502-508. https://doi.org/10.1002/1098-1004(200012)16:6<502::AID-HUMU7>3.0.CO;2-4

[32] Mahdieh, N. and Rabbani, B. (2009) Statistical Study of 35delG Mutation of GJB2 Gene: A Meta-Analysis of Carrier Frequency. International Journal of Audiology, 48, 363-370. https://doi.org/10.1080/14992020802607449

[33] Barış, I., Kılınç, M. and Tolun, A. (2001) Frequency of the 35delG Mutation in the Connexin 26 Gene in Turkish Hearing-Impaired Patients. Clinical Genetics, 60, 452-455. https://doi.org/10.1034/j.1399-0004.2001.600608.x

[34] Tekin, M., Duman, T., Boğoçlu, G., İncesulu, A., Çomak, E., et al. (2003) Spectrum of GJB2 Mutations in Turkey Comprises Both Caucasian and Oriental Variants: Roles of Parental Consanguinity and Assortative Mating. Human Mutation, 21, 
552-553. https://doi.org/10.1002/humu.9137

[35] Chaleshtori, M.H., Farhud, D., Taylor, R., Hadavi, V., Patton, M., et al. (2002) Deafness-Associated Connexin 26 Gene (GJB2) Mutations in Iranian Population. Iranian Journal of Public Health, 31, 75-79.

[36] Sadeghi, A., Sanati, M.H., Alasti, F., Hashemzadeh Chaleshtori, M. and Ataei, M. (2005) Mutation Analysis of Connexin 26 Gene and Del (GJB6-D13S1830) in Patients with Hereditary Deafness from Two Provinces in Iran. Iranian Journal of Biotechnology, 3, 255-258.

[37] Mehri-Ghahfarrokhi, A., Hashemzadeh-Chaleshtori, M., Shojaeian, A. and Mahmoudian Sani, M.R. (2017) Studying Gap Junction Beta 2-Related Deafness in Iranian Population. Otorinolaringologia, 67, 89-95

[38] Denoyelle, F., Marlin, S., Weil, D., Moatti, L., Chauvin, P., et al. (1999) Clinical Features of the Prevalent form of Childhood Deafness, DFNB1, Due to a Connexin-26 Gene Defect: Implications for Genetic Counselling. The Lancet, 353, 1298-1303. https://doi.org/10.1016/S0140-6736(98)11071-1

[39] Seeman, P. and Sakmaryova, I. (2006) High prevalence of the IVS $1+1$ G to A/GJB2 Mutation among Czech Hearing Impaired Patients with Monoallelic Mutation in the Coding Region of GJB2. Clinical Genetics, 69, 410-413. https://doi.org/10.1111/j.1399-0004.2006.00602.x

[40] Bonyadi, M.J., Fotouhi, N. and Esmaeili, M. (2014) Spectrum and Frequency of GJB2 Mutations Causing Deafness in the Northwest of Iran. International Journal of Pediatric Otorhinolaryngology, 78, 637-640.

https://doi.org/10.1016/j.ijporl.2014.01.022

[41] Sirmaci, A., Akcayoz-Duman, D. and Tekin, M. (2006) The c. IVS1 + 1G > A Mutation in the GJB2 Gene Is Prevalent and Large Deletions Involving the GJB6 Gene Are Not Present in the Turkish Population. Journal of Genetics, 85, 213-216. https://doi.org/10.1007/BF02935334

[42] Biyikli, T.A. (2012) Prevalence of the IVS1 (+1) G > A and 35delG Mutations in the GJB2 Gene of Turkish Patients with Nonsyndromic Hearing Loss. Turkish Journal of Biology, 36, 1-6.

[43] Asma, A., Ashwaq, A., Norzana, A., Atmadini, A.M., Ruszymah, B., et al. (2011) The Association between GJB2 Mutation and GJB6 Gene in Non Syndromic Hearing Loss School Children. Med J Malaysia, 66, 125.

[44] Koohiyan, M., Hashemzadeh-Chaleshtori, M., Salehi, M., Abtahi, H., Reiisi, S., et al. (2018) GJB2 Mutations Causing Autosomal Recessive Non-Syndromic Hearing Loss (ARNSHL) in Two Iranian Populations: Report of Two Novel Variants. International Journal of Pediatric Otorhinolaryngology, 107, 121-126.

https://doi.org/10.1016/j.ijporl.2018.01.012

[45] Wang, H., Wu, K., Yu, L., Xie, L., Xiong, W., et al. (2017) A Novel Dominant GJB2 (DFNA3) Mutation in a Chinese Family. Scientific Reports, 7, Article No. 34425. https://doi.org/10.1038/srep34425

[46] Oldak, M., Lechowicz, U., Pollak, A., Ozieblo, D. and Skarzynski, H. (2019) Overinterpretation of High Throughput Sequencing Data in Medical Genetics: First Evidence against TMPRSS3/GJB2 Digenic Inheritance of Hearing Loss. Journal of Translational Medicine, 17, Article No. 269. https://doi.org/10.1186/s12967-019-2018-9

[47] Schrauwen, I., Chakchouk, I., Acharya, A., Liaqat, K., Irfanullah, et al. (2018) Novel Digenic Inheritance of PCDH15 and USH1G Underlies Profound Non-Syndromic Hearing Impairment. BMC Med Genet, 19, Article No. 122. 
https://doi.org/10.1186/s12881-018-0618-5

[48] Liu, X.Z., Yuan, Y., Yan, D., Ding, E.H., Ouyang, X.M., et al. (2009) Digenic Inheritance of Non-Syndromic Deafness Caused by Mutations at the Gap Junction Proteins Cx26 and Cx31. Human Genetics, 125, 53-62.

https://doi.org/10.1007/s00439-008-0602-9

[49] Kim, S.Y., Kim, A.R., Kim, N.K., Lee, C., Kim, M.Y., et al. (2016) Unraveling of Enigmatic Hearing-Impaired GJB2 Single Heterozygotes by Massive Parallel Sequencing: DFNB1 or Not? Medicine (Baltimore), 95, e3029.

https://doi.org/10.1097/MD.0000000000003029

[50] Chen, K., Wu, X., Zong, L. and Jiang, H. (2018) GJB3/GJB6 Screening in GJB2 Carriers with Idiopathic Hearing Loss: Is It Necessary? Journal of Clinical Laboratory Analysis, 32, e22592. https://doi.org/10.1002/jcla.22592

[51] Wu, B.-L., Lindeman, N., Lip, V., Adams, A., Amato, R.S., et al. (2002) Effectiveness of Sequencing Connexin 26 (GJB2) in Cases of Familial or Sporadic Childhood Deafness Referred for Molecular Diagnostic Testing. Genetics in Medicine, 4, 279-288. https://doi.org/10.1097/00125817-200207000-00006

[52] Rickard, S., Kelsell, D.P., Sirimana, T., Rajput, K., MacArdle, B., et al. (2001) Recurrent Mutations in the Deafness Gene GJB2 (Connexin 26) in British Asian Families. Journal of Medical Genetics, 38, 530-533. https://doi.org/10.1136/jmg.38.8.530

[53] Hashemzadeh Chaleshtori, M., Farhoud, D. and Patton, M. (2007) Familial and Sporadic GJB2-Related Deafness in Iran: Review of Gene Mutations. Iranian Journal of Public Health, 36, 1-14.

[54] Marlin, S., Garabédian, E.-N., Roger, G., Moatti, L., Matha, N., et al. (2001) Connexin 26 Gene Mutations in Congenitally Deaf Children: Pitfalls for Genetic Counseling. Archives of Otolaryngology-Head \& Neck Surgery, 127, 927-933. https://doi.org/10.1001/archotol.127.8.927

[55] Meşe, G., Londin, E., Mui, R., Brink, P.R. and White, T.W. (2004) Altered Gating properties of Functional Cx26 Mutants Associated with Recessive Non-Syndromic Hearing Loss. Human Genetics, 115, 191-199.

https://doi.org/10.1007/s00439-004-1142-6 